\title{
Brian O'KEEFFE
}

Barnard College, New York

Review of:

SCOTT, Clive (2018):

The Work of Literary Translation. Cambridge: University Press. 285 p. ISBN: 978-1-108-44581-8

\section{Engaging with Translation. New Readings of George Steiner's After Babel}

Marco Agnetta Larisa Cercel Brian O'Keeffe [eds.]

Yearbook of Translational Hermeneutics Jahrbuch für Übersetzungshermeneutik

Journal of the Research Center Zeitschrift des Forschungszentrums

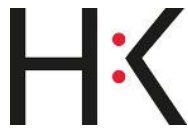

\section{(c) (i) (2) (2)}

Cite this article:

O'Keeffe, Brian (2021): „Review of: SCOTT, Clive (2018): The Work of Literary Translation.

Cambridge: Cambridge University Press. 285 p. ISBN: 978-1-108-44581-8“. In: Yearbook

of Translational Hermeneutics 1, pp. 373-380. DOI: <10.52116/yth.vi1.34>. 
Brian O'KEEFFE

Barnard College, New York

\section{Review of: SCOTT, Clive (2018): The Work of Literary Trans- lation. Cambridge: Cambridge University Press. 285 p. ISBN: 978-1-108-44581-8.}

"Translation," Clive Scott writes, "is an exploration, palpation and inscription into the source text" (p. 2). Inscription: this can involve writing that scribbles and doodles, writing that isn't shy of marking pages with handwriting-pages scored and re-scored with Scott's pen's nib, imprinted by different inks or by the greys of a lead pencil. When Scott translates, he is thoroughly co-present with the source-text-there, right there, on the poem's surface. Palpation: translation feels the poem's pulse, re-handles the poem, explores its concinnities, samples and adjusts its sound-scape. The Work of Literary Translation wonderfully explores translation's creative licence - the source-text poem resembles an instrument that can always be re-tuned, or re-strung like a guitar. Or else it resembles a Cezanne painting - always soliciting variations of visual focus, always amenable to translations that look again and look differently, sometimes aslant, sometimes with intense tunnel vision.

Like many recent contributions to translation studies, Scott seeks to displace what Lawrence Venuti (2019: 1) calls "instrumentalism"- - the sedulous concern for translatory fidelity, exactitude, and equivalence. Scott's book operates that displacement in respect of literature and especially poetry. One question Scott poses therefore is whether translation should seek to refine rule-bound methodologies or "is it part of the work of translation to resist methodologies?” (p. 6) If resistance is preferable, then Scott resiles from proposing another theory of translation, preferring instead to sketch the lineaments of "a philosophy of translation" (ibid.: 9). The task of the present review is to present aspects of that philosophy, and to show why it's not yet another theory of translation. Nor yet another theory of "untranslation". Consider: 
A translation is not the (attempted) (re)expression of something already expressed in the ST; it is, on the contrary, what the ST has not expressed, has not been in a position to express. If one thinks of translation as reciprocal exchange, then something identified as an untranslatable element in the ST is itself a failure to translate what the TT chooses to translate it by. (P. 18)

The source text poem already struggles with untranslatability (think of Mallarmé's struggle to evoke the scent of an absent bouquet of flowers). So it's unwise to declare "untranslatable" something the original poem does evoke-it may rather be that "untranslatable" describes what it doesn't evoke. Perhaps the translator's task to supply an echo-chamber in order to belp the poem express itself. "The question should never be: can it be translated or not? Nor: is translation an impossible task that nevertheless can be done? It should rather be: what kind of process is translation? What kind of relationship does translation strike up with the ST?" (p. 32) These remarks emerge in the course of a disagreement with Derrida's propositions on translatability and untranslatability. Scott cites from Derrida's Monolingualism of the Other:

From the moment this economic equivalence-strictly impossible, by the way - is renounced, everything can be translated, but in a loose translation, in the loose sense of the word 'translation'... In a sense, nothing is untranslatable; but in another sense, everything is untranslatable; translation is another name for the impossible. (Derrida 1998, cited at p. 32).

It's clear that Derrida resists economic scenarios where translation becomes a matter of costs, accounting and (symbolic) recompense. But consider "from the moment": is that renunciatory moment possible? The question of that moment focuses what I think is persistently missed in commentaries on Derrida's way with (un)translatability, namely the question of time, and the gift of infinite time awarded to a translator such that she might take the time to solve all translatory dilemmas. Since that gift (Derrida insists on this in Given Time 1) has never been given, then - for Derrida, at least - it is permissible to contemplate translatory impossibility, or indeed the concept of the impossible.

At any rate, Scott's effort to dispel peremptory talk of untranslatability significantly takes aim at the tendency to regard translation as a bilingual interaction-texts translated from one language into 
another one. But "[b]ilingualism makes translation a colonizing force, an activity which either destroys (the translatable) or fossilizes (the untranslatable) the perception of cultural difference" (p. 21). Translation colonizes when it replaces one language by another, the original by the translation. But "replacement" translates so successfully that cultural difference is translated away, so to speak (and we might not notice that translation ever occurred at all). When translation acknowledges resistances to its activity, however, and calls such resistances untranslatabilities, then translation halts. Cultural diversities and disparities are dragooned into the (philosophical?) precincts of the categorial-we speak of Otherness, of an alterity that seemingly forbids any kind of comprehending interaction at all. Whence Scott's enlistment of Édouard Glissant_- "relation" is what we need, rather than un-bridgeable gulfs between self and other, ST and T'T. Needed is a polyglot reader for whom "translation is the opportunity to witness not a negotiation of differences between languages, but the mutual desire of languages to exercise themselves in unsuspected expressive capacities, to make themselves permeable to other cultural presences" (p. 101).

What is translation for Scott? Translation isn't an act of interpretation. Translational Hermeneutics (and perhaps Venuti, reviewed in this volume as well) would be brought up short by that. But for Scott, "The interpretative ambition, to nail the text's meaning, is, quite simply, a mirage" (p. 56). Some hermeneutic models agree that there can be no such "nailing", but other models still seek to establish the limits of interpretation (Gadamer, perhaps, on behalf of his 'classic' texts). Yet Scott's disinclination to regard translation as an interpretative act (if that means nailing meaning) is motivated by a desire to stop translation from becoming an exercise in winnowing down interpretative choices, vis-à-vis a portion of the source text, to just one-to the putatively best one. For that does nail things down: a decision is taken and so the source text's meaning 'congeals' around that very choice. Scott prefers to choose-without-choosing (to sound like Derrida): he opts for one departure point, travels a translatory path for a while, but never 
ends up at a fixed destination. Turn back, re-commence, break a new path. Keep choosing, so as never to decide.

We lack, Scott argues, a sense of the translator's activity. A philosophy of translation could help by providing a phenomenology of reading. But "we have no concept of the practising reader" (p. 14). No concept of the practicing translator either, therefore. There are phenomenological accounts of reading, however: one thinks of Ingarden, Iser, or indeed Worringer. But perhaps such phenomenologies drift too far from what actually occurs when readers and translators engage with texts. Perhaps "text" is too vague, moreover, since we must also recognise that reading engages with the paper page. To invoke Paul de Man, we must address materiality and inscription, and resist the phenomenalisation of written texts whereby they become schematic constructs, as if 'worlds' accessible to a reader's imagination, but where the activity of imagining seems to bypass or supercede the difficult activity of reading. When that happens, we lose the opportunity to engage with writing, to read writing, and moreover appreciate the grain of the page.

De Man, however, would be suspicious of Scott's appeal to Merleau-Ponty's account of visual perception for that reason. Evidently, we need to see the writing on the page. But if "Translation is the means by which we bring the ST back into play, make it not only the seen but the seeing, not only the visible but also that which is packed with invisible" (p. 92), de Man might ask why accounts of reading-and translation-resort to visual metaphors (and this is surely a metaphorical use of 'visible' and 'invisible'). Doesn't that just re-phenomenalise texts, remove the materiality of the page, and turn texts into some kind of optical medium? Yet any reader attuned to Mallarmé and Apollinaire will reply that some poems make pictures and hence invite readers to encounter "perceptual vicissitude" (p. 107) as they behold their textual space. If so, why not regard translation as a spatial encounter and experiment with avantgarde strategies of montage and collage - cut-and-paste jobs on source texts? Scott does precisely that: his translations resemble Futurist re-creations - textual portions are snipped and re-assembled, fonts and typefaces are changed, paint splotches and doodled 
curlicues draw the eye towards and away from morsels of re-printed text. Each experiment is accompanied by thoughtful commentary on the poem's original rhyme-scheme. But, like a piano-tuner, Scott flicks the tuning-fork in order to detect different consonances, and suggest different orchestrations of the poem's original song.

Scott has a keen ear and excellent vision. Translation can move "from the linear towards the tabular" in order "to generate a planar perceptional mode" (p. 143). Planar perception: here's the justification for invoking Merleau-Ponty, Cezanne, and for his resistance (although Scott doesn't put it this way) to Foucault's triangle of representation where the visual field is commandeered at the apex, stabilised therefore for an eye that encounters nothing 'fractal' nor suffers the liabilities of the mottled screen and the parallax view.

We should appreciate the "paginal art of translation" (p. 165). Translation should attend to the "stagecraft of a particular page" (p. 167). And, if we wish to stress poetry's acoustic dimensions, translation should be inspired by the sonic slicing-and-dicing of electronic music: "Translation is $[. .$.$] the writing equivalent of$ digital sampling, of the mash-up" (p. 137). Philosophical support comes from Deleuze: when Scott writes that "Translation is not a transcriptive act but a matricial one, that by which the ST assumes a new guise in the TT, a new capacity for rhizomatic ramification" (p. 45), the Deleuzian rhizome helps to re-describe the act of translation. May translation help original texts become, proliferate, and enjoy their arborescence! Support also comes from Derrida insofar as what is at issue is a translatory practice supplying alternative spaces "into which the text can expand in a movement of dissemination" (p. 168).

Speaking of Derrida (again), I am struck by Scott's remark: "Any text is inhabited by, absorbs, a phantomatic linguistic accompaniment" (p. 51). And, referring to the language of translation, it's a matter of "a langage which ghosts the langue while speaking with a different tongue" (p. 39). Translation-as-hauntology: an exercise in contemplating occult linguistic potentialities, albeit in terms of a langage that shadows all natural languages with a phantomal language 
no one actually speaks (and which isn't Benjamin's reine Sprache either) but which enflames our Pentecostal desires, offering itself as a practical possibility for new linguistic expression. (Specialists of untranslatability, for their part, bid for impossibility. Translation-asuntranslation: an exorcism of the possible, you might say.)

I've always been struck by the idea that translation casts, throws, or projects original texts beyond themselves - into a spectral half-life perhaps, but, in any case, geworfen into a translation zone that is hazardously elsewhere or otherwhere, remote from philosophy's assured cartographies and ontologies of "thereness". Scott, for his part, throws source texts into the ocean: translation "retools' the ST, such that it must forgo its autonomy, and yield its land-based existential mode to an oceanic one" (p. 160). Joseph Conrad: our unacknowledged translation studies theorist? It's a thought. Scott claims:

The source culture becomes itinerant, nomadic, in order that the target culture can equally become itinerant, nomadic. In this sense, translation frees all participating cultures from their respective States. But clearly they do not then fuse together to form some global lingua franca, but rather become an oceanic flux, that is to say, they resituate the land and its demarcated territories in the ocean, in a space of polymorphous relationships, of the free play of intersection and transaction. (P. 242)

We're not done with our maritime metaphors, I think. Itinerancy and nomadism figured as seafaring voyages; translation as a thalattography resistant to 'terran' thoughts of moored fixities; original texts invited to embark on what, to adapt Foucault, we might call translation's heterotopic boat. But, as translation sails towards its briny horizons, it must avoid the Sargasso Sea of instrumentalism and embrace the dip and swell of pelagic postmodernism: "This is all, finally, to promote not a postmodern version of translation but the idea that translation is constitutionally postmodern" (p. 12). Let that claim linger in the minds not just of Translational Hermeneutics specialists, but also those who might have read my review of Venuti's Contra Instrumentalism (see below), since he also appeals for postmodernity. Certainly, the value of Scott's book is that we gain a sense of what that postmodernism looks like in practice. 
Yet that entails a phenomenology of reading that involves Scott describing what he was thinking, seeing, feeling, and pulsing to. Scott describes his own divagatory consciousness, his distractions and attentions, his passivities and activities, and the setting for his translation experiments-one matter is that "translation has the specific task of restoring its reading environment(s) to the text" (p. 54). I agree.

That's part of the agenda Scott sets before us. Admittedly, the agenda is narrowed to literary translation and is squarely designed to challenge the current ethos of comparative literature studies. But there is a broader thrust nevertheless when he speaks of "a new comparative-literature-of-the-reader [which would turn] comparative literature in a projective direction" (p. 118), and that, despite a certain "apparently reckless and arbitrary associative anarchy" (p. 118). Read alongside Scott's claim for translation's constitutive postmodernism, we might appreciate that anarchy can be a projective search for new directions not just for comparative literature, but for translation studies. Some bristle at postmodernism and condemn its (apparent) anarchy, however. But a dose of anarchy is no bad thing if it jolts translation studies out of its routines, and perhaps also out of an aestheticism, when matters concern literary translation, that is either too cumbersome or too delicately vague (Frost: poetry is what gets lost in translation). Scott is correct to say that "aesthetics has made little headway with any formulation of an aesthetic of the dynamic, of the unsettled, the self-diversifying, the metamorphic" (p. 138). Head away from Kant, then, and towards Deleuze and postmodernism, and towards Scott's own path-breaking book. But know your fellow travelers. Scott hesitates over Barthes, for instance, but when Barthes envisages the scriptible, writerly text, then perhaps we might say that all texts are writeable, amenable to the (re-)writing that is translation. That might be the postmodern vista opened up by Barthes, despite Barthes' relatively narrow canon of writerly texts. Writeability, translatability: whatever "-ability" talk one hears in and around (un)translatability, the fact is that translators enable texts. They foster new abilities for source texts. They do so with dextrous exuberance and hence lib- 
erate source texts from the prison-house of original languages. Translators are turnkeys, unlatch the cell doors, and release texts from their penitential housing in monolingualism. Translation liberates texts into their expressive futures. Thinking about translation often involves thinking about time itself. So for Benjamin, for Derrida, and for Scott. Scott's approach to translation shows us how not to choose a text's future, and how, instead, to foster the coming and becoming of texts - to hold open the time of their unpredictable to-come.

\section{References}

DERRIDA, Jacques (1998): Monolingualism of the Other; or, The Prosthesis of Origin. Translated by Patrick Mensah. Stanford: Stanford University Press.

VENUTI, Lawrence (2019): Contra Instrumentalism. A Translation Polemic. Lincoln: University of Nebraska Press.

Lucia SALVATO

Università Cattolica del Sacro Cuore, Milan

Review of: SHPET, Gustav (2019): Hermeneutics and Its Problems. With Selected Essays in Phenomenology. Edited and translated by Thomas Nemeth. Springer Nature Switzerland AG. 304 p. ISBN: 978-3-319-98940-2.

'Im Ensemble der Geisteswissenschaften', since its development in the second half of the $20^{\text {th }}$ century translation hermeneutics has gained particular relevance in relation to human communication and human mental activity in general. At the same time, the study of human sciences, as well as the exercise of translation hermeneutics with respect to the need to understand foreign texts prior to proceeding further, were the object of Sphet's cultural and linguistic interests. 